\title{
СЕМАНТИЧНИЙ АНАЛІЗ СИНОНІМІВ НОМІНАТИВНОЇ ЛЕКСЕМИ КОНЦЕПТУ FАМILY
}

\author{
Ірина Матіяш-Гнедюк
}

\begin{abstract}
Прикарпатський національний університет імені Василя Стефаника, вул. Шевченка, 57, м. Івано-Франківськ, Украӥна, 76000

irynamatiiashhned@gmail.com
\end{abstract}

\begin{abstract}
У статті зроблено спробу проаналізувати синоніми концепту FAMILY на основі здійсненого лексикографічного аналізу синонімів номінативної лексеми концепту, угрупувавши їх у синонімічні ряди і розглянувши відтінки значень синонімів. Розглянуто тезу про те, що одним із етапів моделювання структури концепту є аналіз синонімів лексеми-імені концепту з метою вичерпного аналізу понятійного складника концепту, який досліджується. Виявлено, що 1) в межах синонімічного ряду слова групуються на основі семантичної спільності, а між собою вони різняться відтінками, вживанням, емоційним забарвленням тощо; 2) синонімічний ряд організовується навколо однієї лексеми (домінанти), значення якої є спільним для всіх синонімів цього ряду. Визначено синонімічні лексеми іменника-імені аналізованого концепту за допомогою семи словників синонімів і тезаурусів. Виокремлено сім синонімічних рядів, визначено домінанту кожного ряду та проаналізовано їхнє наповнення.

Ключові слова: синонімія, синонімічний ряд, домінанта, лексема, концепт.
\end{abstract}

Вступ. Кінець XX - початок XXI ст. у мовознавчій науці характеризується підвищеним інтересом до когнітивних розвідок, зокрема збільшується кількість досліджень концептів та їхньої динаміки. Оскільки концепт відіграє активну роль у мисленнєвому процесі і поєднується із іншими концептами, прийнято вважати, що він має "гнучку" будову [19, с. 58].

Згідно зі структурою концепту за З. Д. Поповою та Й. А. Стерніним [15, с. 101-152], виокремлюють три основних етапи його дослідження:

1) аналіз ключових слів-репрезентантів концепту у мові;

2) побудова та аналіз семантичного простору ключового слова-вербалізатора концепту у мові;

3) аналіз синонімів ключового слова-вербалізатора концепту у мові.

Розгляд синонімів імені концепту необхідний для виявлення додаткових понятійних ознак концепту. Окрім того, моделювання структури концепту буде неповним без аналізу синонімічного ряду його лексеми-імені.

Аналіз останніх досліджень і публікацій. Питання синонімії посідає окреме місце в характеристиці лексичного складу мови, оскільки синонімічні зв'язки слів $€$ наочним доказом її системної організації, а синонімічні ряди можна трактувати як мікросистеми.

(C) Матіяш-Гнедюк I., 2019 
Виникнення терміна “синонімія” відносять до часів М. Ф. Квінтиліана (IV ст. н.е.). Як зазначає В. А. Василенко, “ще давні греки дійшли висновку, що саме в синонімах виражається багатство мови. Римські вчені усвідомили не тільки схожість слівсинонімів, але й різницю між ними" [1, с. 46].

Явище синонімії стало об'єктом багатьох лінгвістичних досліджень українських та зарубіжних учених (Ю. Д. Апресян, В. А. Басок, С. Г. Бережан, А. О. Брагіна, I. Т. Вербовська, Г. О. Винокур, Я. С. Думашівський, В. А. Звєгінцев, Н. Г. Іщенко, М. П. Кочерган, О. І. Малиновська, О. М. Мітіна, О. І. Нечитайло, О. О. Тараненко, Г. А. Уфімцева, Н. Л. Щербина, та ін.).

Існує плюралізм у тлумаченні терміна “синонім”. За Ю.С. Степановим, синоніми це слова, схожі за значенням, для яких важливе відношення до денотата та сигніфіката. Звідси, синоніми є “такими лише тоді, коли вони належать до одного денотата, або коли позначають одне поняття" [18, с. 30]. Учений стверджує, що “лінгвісти часто не враховують устрій слова, а також те, що воно включає і відношення до предмета, і до поняття" [Там само].

За Ю. Д. Апресяном, виокремлюють два основні підходи до означення синонімів: семантичний та операційно-семантичний. Відповідно до першого підходу, синонімами $\epsilon$ слова, що мають однакове лексичне значення, але різняться відтінками: “Спроба об'єднати поняття про синонімію як семантичну тотожність із поняттям про синоніми як слова, які можуть відрізнятися один від одного лише за значенням, привела до концепції нейтралізації семантичних відмінностей у чітко окреслених позиціях, що виражаються семантичними, лексичними, синтаксичними та іншими ознаками” [5, с. 217-218].

Вважають, що синоніми належать до однієї частини мови, але на думку I. М. Кобозєвої, “до синтаксичних синонімів повинні належати й ті слова, які при збігу за денотативним, сигніфікативним та прагматичним значеннями відрізняються лише своєю приналежністю до певної лексико-граматичної категорії” [11, с. 100].

У нашому дослідженні за основу взято визначення Ю. Д. Апресяна, який називає синонімами слова, що мають однакове лексичне значення, але відрізняються за відтінками.

У межах теорії синонімії одним із ключових питань $є$ проблема синонімічного ряду, який трактують як мікросистему в синонімічній системі та загальній системі мови. Характеристикою цієї мікросистеми є можливість різної номінації одного і того самого явища чи предмета об'єктивної дійсності. Як наголошує Р. А. Будагов [9, с. 30], у кожному синонімічному ряді ми бачимо і спільне (те, що пов'язує синоніми, робить ïx представниками одного широкого поняття), і відмінне (те, що уможливлює кожен синонім ряду підкреслити лиш окремий аспект поняття). Група синонімів утворює певну єдність, оскільки вони, позначаючи одне поняття, характеризують його з різних сторін.

Традиційно побудова синонімічних рядів грунтується на таких критеріях:

1) відображення “одного і того ж явища об’єктивної дійсності” [13, с. 31];

2) спільність чи тотожність значень [4, с. 540; 22, с. 11; 16, с. 407];

$3)$ тотожність лексичного значення і відповідність семантичних валентностей $[5$, c. 223];

4) можливість функціональної заміни [23, с. 66; 10]. 
Отже, синонімічний ряд можна визначити як сукупність слів і семантично рівнозначних їм словосполучень, що вживаються для вираження того самого поняття, того самого явища об'єктивної дійсності [12, с. 447]. Синонімічний ряд характеризується семантичною спільністю всіх членів цього ряду, тобто спільністю поняття, яке вони позначають. Так утворюється смислова основа, яка є підставою для включення слів до синонімічного ряду: “В межах синонімічного ряду слова об'єднуються на основі їх смислової співвідносності, а між собою в середині ряду відрізняються або певними відтінками значень, або емоційним забарвленням, або сферою вживання. Тому не завжди слова одного синонімічного ряду можуть заміняти одне одного" [3, с. 161]. Формуючи синонімічний ряд, необхідно чітко визначити, в якому саме значенні вживається слово і в якому значенні відносимо його до певного ряду, оскільки часто слова є полісемантичними. Одне і те ж слово може в різних значеннях входити до різних рядів, тому важливо не об'єднувати і не змішувати ряди із однаковими складовими.

Синонімічний ряд утворюється навколо певної лексеми, значення якої $\epsilon$ спільним для всіх синонімів ряду. Таку лексему називають опорним словом, центром синонімічного ряду (А. П. Свгеньєва), домінантою (Ю. Д. Апресян). Домінанта “... найбільш чітко передає поняття, яке позначають слова синонімічного ряду. Таким найчастіше є слово в основному номінативному значенні, яке прямо і безпосередньо відображає зв' язок із предметом, явищем, поняттям ... без додаткових (експресивних, емоційних, стилістичних) елементів" [17, с. 17]. За Ш. Баллі, домінанта має виражатись в найпростішій, об' єктивній і найбільш абстрактній формі, вона не повинна містити специфічної інформації про поняття, яке позначає, а лише основні ознаки, які притаманні усім іншим синонімам ряду [7, с. 129-138]. Ю. Д. Апресян додає, що домінанта є “найбільш уживаним синонімом, характеризується найповнішою парадигмою, найширшим набором синтаксичних конструкцій, найбільшою сполучуваністю...” [6, c. 219].

Проте поняття домінанти синонімічного ряду не є однозначним. Статус домінанти не доведений і піддається критиці [8, с. 126-127; 20, с. 33]. Аналіз мовного матеріалу нерідко показує, що виокремлення домінанти у певних синонімічних рядах $є$ неможливим, оскільки вона не $\epsilon$ втіленням загальної інтегральної семи усіх синонімів. За В. Д. Черняк, “спільну сему чи ядерні семи важко передати через одне словодомінанту. Загальне значення синонімічного ряду не може тлумачитись однослівно" [21, с. 23]. Тобто, наявність загальноприйнятого підходу і критеріїв виділення домінанти не гарантує правильного її визначення на практиці. Тому у цій розвідці ми трактуємо домінанту як нейтральну лексему, яка лише називає поняття, не конкретизує його і не відображає його характерних особливостей.

Серед вітчизняних і закордонних досліджень концептів аналіз синонімів до лексеми-вербалізатора концепту з метою виявлення його додаткових понятійних ознак можна знайти у працях Е. В. Довганюк (концепт КРАСА), Н. Г. Єсипенко (концепти FREEDOM, HOME), М. В. Ковалюк (концепт LANGUAGE), Н. Є. Пилячик (фреймовий концепт ЯВИЩА ПРИРОДИ), О. Я. Сурмач (концепт БАГАТСТВО), Г. Є. Маханової (концепт СКУКА) та ін. 
Головною метою цієї роботи є аналіз лексичних одиниць із синонімічними значеннями до імені концепту FAMILY на основі лексикографічного аналізу. Розгляд синонімів уможливлює виявлення додаткових когнітивних ознак концепту (М. М. Болдирєв, С. Г. Воркачов, З. Д. Попова, Й. А. Стернін та ін.). Окрім того, аналіз синонімів доповнить результати проведених нами раніше дефініційного і компонентного аналізів концепту FAMILY [2].

Необхідність дослідження синонімів до імені концепту наголошує, зокрема М. В. Піменова [14, с. 143], зауважуючи, що, оскільки ім'я концепту передає його зміст частково, то для його повної репрезентації існують ряди синонімів.

Методологія дослідження. Викладене у цій статті дослідження проведено у три етапи. На першому етапі за допомогою 7 словників синонімів і тезаурусів (Oxford Living Dictionaries, Collins English Dictionary, Merriam-Webster Online Dictionary and Thesaurus, Webster's All-In-One Dictionary and Thesaurus, Roget's $21^{\text {st }}$ Century Thesaurus, The synonym Finder, Roget's Thesaurus of English words and phrases) визначено усі синонімічні лексеми іменника-імені аналізованого концепту FAMILY.

Другий етап передбачає організацію синонімів у ряди на основі наявності спільної семи у значеннях синонімів. Відповідно, було виокремлено сім синонімічних рядів та визначено їхні домінанти. На третьому етапі було здійснено опис семантики наповнення кожного синонімічного ряду.

Результати дослідження та їхнє обгрунтування. За кількісним наповненням синонімічні ряди розташовуються у такому порядку: 1) “група людей, об’єднаних за критерієм спільного походження”, 2) “група людей, об’ єднаних кровними чи шлюбними зв’язками”, 3) “група однорідних, схожих між собою предметів, явищ”, 4) “діти особи чи пари”, 5) “група людей, об’єднаних за критерієм спільності інтересів, переконань, діяльності”, 6) “соціальна група", 7) “шляхетне походження”.

До першого синонімічного ряду, “група людей, об'єднаних за критерієм спільного походження”, належать такі синоніми: ancestors, forebears, parentage, forefathers, house, line, generation, birth, strain, stock, sept, clan, gens, descent, dynasty, pedigree, extraction, ancestry, lineage, genealogy, line of descent, stemma, stirps, origin, derivation, progenitors, heredity, antecedents, background, roots, past, history, family tree. Синоніми цього ряду об'єднані семою 'lineage', що вказує на групу людей, які походять від спільного предка та утворюють один рід чи родину. Домінантою вважаємо синонім genealogy, оскільки він $є$ узагальнювальним і охоплює усіх членів родини: як живих, так і мертвих, тих, які є нащадками і тих, які є предками.

Другий синонімічний ряд - “група людей, об’єднаних кровними чи шлюбними зв'язками” - утворюють такі синоніми: relatives, relations, blood relations, blood tie, consanguinity, household, ménage, family members, parents and children, parentage, patrimony, paternity, siblings, in-laws, kin, next of kin, kinsfolk, kinsmen, kinswomen, kindred, one's flesh and blood, connections, extended family, fam (informal), folks, nearest and dearest, clan, people (dated). Спільна для них сема - 'relation'. Вона характеризує усі можливі родинні зв'язки людини через шлюб чи кровну спорідненість. Синонім relatives виокремлюємо як домінантний у цьому ряді на основі його універсальності для позначення будь-яких родичів. 
Третій синонімічний ряд - “група однорідних, схожих між собою предметів, явищ” - містить species, group, grouping, department, class, system, order, kind, network, genre, classification, subdivision, subclass, category, division, genus, grade, league, rank(s), rubric, set, type, section, fashion, stamp, brand, ilk, taxonomic group, branch. Спільна сема 'group of things' може бути виокремлена із лексичного значення кожного зазначеного синоніма. Відповідно, домінантою буде синонім group, який найбільш вдало описує увесь ряд i сам може використовуватись в якості синоніма до кожної лексеми цього ряду.

Четвертий синонімічний ряд (“діти особи чи пари”) складається із синонімів children, kids (informal), infants, offspring, little ones, munchkins (informal), littlies (informal), young, youngsters, babies, seed, successors, heirs, scions, assign, descendant, issue, spawn (derogatory), posterity, tots, sprogs. Синоніми цього ряду об'єднуються семою 'descendant', яка вказує на факт прямого походження однієї особи від іншої. Домінанта - children, як нейтральна і загальна лексема для позначення нащадків.

П'ятий синонімічний ряд - “група людей, об'єднаних за критерієм спільності інтересів, переконань, діяльності” - утворюється із синонімів: society, caste, brotherhood, sisterhood, sorority, association, branch, gang, mafia, underworld, community, company, network, affiliation, fraternity, band, organization, fellowship, school. Спільна сема 'group of people' входить до семантичної структури кожного синоніма. Домінантою вважаємо синонім association, який характеризує угруповання людей на основі однакових цілей, роботи, інтересів, поглядів, переконань, вірувань, тощо.

Шостий синонімічний ряд (“соціальна група”) охоплює такі лексичні одиниці, як race, ethnic group, tribe, folk, nation, people, social group. Цей ряд синонімів об'єднується тією ж семою, що і попередній ('group of people'), проте домінантна лексема social group вказує на диференційну ознаку цього ряду - сукупність людей, які утворюють соціальні групи (народ, плем'я, етнічна група тощо).

Сьомий синонімічний ряд - "шляхетне походження" - складається із синонімів nobility, noble birth, high birth, aristocracy, blue blood. Подані синоніми містять спільну сему, яка вказує на приналежність до вищого класу у суспільстві. Синонім aristocracy виокремлюємо як домінантний, оскільки він позначає як приналежність до аристократів, так і до вищого класу без титулу.

Порівняємо виявлені понятійні ознаки аналізованого концепту FAMILY із основним лексичним значенням імені цього концепту. Зокрема, дефініція "Family - a group of people who are related to each other, such as a mother, a father, and their children" [22] містить семи 'relation', 'group', 'descendant', 'father', 'mother', які входять до другого і четвертого синонімічних рядів. Проте зазначимо, що сема 'group' є експліцитною для п'ятьох синонімічих рядів (“група людей, об' єднаних кровними чи шлюбними зв'язками”, “група людей, об'єднаних за критерієм спільного походження”, “група однорідних, схожих між собою предметів, явищ”, “група людей, об'єднаних за критерієм спільності інтересів, переконань, діяльності”, “соціальна група”). У вказаних випадках, окрім першого, ця сема $є$ виразником додаткових понятійних ознак. Ще одна ознака міститься у сьомому синонімічному ряді (“шляхетне походження”). Отже, у цій статті виявлено такі додаткові понятійні ознаки концепту FAMILY: group of things, genealogy, association, social group, aristocracy. 
Висновки та перспективи подальших досліджень. У результаті дослідження побудовано сім синонімічних рядів до імені концепту FAMILY. Аналіз синонімів показав, що п'ять із семи рядів групуються довкола інтегральної семи 'група', чотири із яких містять специфікацію 'група людей, які... ', один - об'єднує синоніми із інтегральною семою 'група речей'. Три синонімічні ряди утворюються довкола домінант із інтегральною семою 'спільність біологічного походження', але із різними диференційними компонентами. Один синонімічний ряд акцентує класовий аспект поняття актуалізованого лексемою-іменем концепту. Також виявлено додаткові понятійні ознаки: group of things, genealogy, association, social group, aristocracy.

Отже, конструювання синонімічних рядів до лексеми-імені концепту FAMILY уможливило виявлення додаткових диференційних понятійних ознак цього концепту. Кожен синонімічний ряд постає як своєрідна єдність, оскільки вони, позначаючи одне поняття, уточнюють, конкретизують, характеризують його з усіх можливих сторін і утворюють номінативне поле концепту. Виокремлені на основі лексикографічних довідників зазначені понятійні ознаки концепту FAMILY є узагальненими і найбільш типовими. Вони не вказують на культурну чи ціннісну ознаки, хоча потенційний розгляд досліджуваного концепту в дискурсі дасть можливість виявити його образно-ціннісний складник.

\section{СПИСОК ВИКОРИСТАНОЇ ЛІТЕРАТУРИ}

1. Василенко В. А. Синонімія і антонімія у поезіях Ігоря Муратова : автореф. дис. ... канд. філол. наук : спец. 10.02.01 “Українська мова” / В. А. Василенко. - Харків, 1999. $-22 \mathrm{c}$.

2. Матіяш-Гнедюк I. M. Аналіз понятійного складника структури концепту FAMILY (діахронний аспект) / І. М. Матіяш-Гнедюк // Закарпатські філологічні студії. - Вип. 5. - Том 1. - Ужгород, 2018. - С. 73 - 77.

3. Пашковська Н. Ф. Синонімічний ряд як мовна мікросистема / Н. Ф. Пашковська // Актуальні проблеми української лінгвістики: теорія і практика. - Вип. 15. - 2008. C. $158-165$.

4. Селіванова О. О. Лінгвістична енциклопедія / О. О. Селіванова. - Полтава : Довкілля-К, 2010. - 844 с.

5. Апресян Ю. Д. Избранные труды. Т. 1. Лексическая семантика (синонимические средства языка) / Ю. Д. Апресян. - Москва : Шк. “Языки рус. культуры”, 1995. - 472 с.

6. Апресян Ю. Д. Исследования по семантике и лексикографии: Т. 1: Парадигматика / Ю. Д. Апресян. - Москва, 2009. - 568 с.

7. Балли Ш. Французская стилистика. 2-е изд., стереотипное / Ш. Балли. - Москва : Эдиториал УРСС, 2001. - 392 с.

8. Белов В. А. Типы синонимических рядов / В. А. Белов // Вопросы психолингвистики. - Том 22.- Москва : “Московская международная академія", 2014. - С. 125-137.

9. Будагов Р. А. Очерки по языкознанию / Р. А. Будагов. - Москва, 1953. - 300 с.

10. Звегинцев В. А. Замечания о лексической синонимии / В. А. Звегинцев // Вопросы теории и истории языка: Сборник в честь проф. Б. А. Ларина. - Ленинград, 1963. С. $137-138$.

11. Кобозева И. М. Лексическая семантика : учебник. / И. М. Кобозева. - Москва : Эдиториал УРСС, 2000. - 352 c. 
12. Лингвистический энциклопедический словарь / гл. ред. В. Н. Ярцева. Москва : Советская энциклопедия, 1990. - 685 с.

13. Палевская М. Ф. Синонимы в русском языке / М. Ф. Палевская. - Москва, 1964. $120 \mathrm{c}$.

14. Пименова М. В. Концептуальные исследования. Введение : учеб. пособие / М. В. Пименова, О. Н. Кондратьева. - Москва : ФЛИНТА ; Наука, 2011. - 176 с.

15. Попова 3. Д. Очерки по когнитивной лингвистике / 3. Д. Попова, И. А. Стернин. - Воронеж : Истоки, 2001. - $191 \mathrm{c.}$

16. Словарь лингвистических терминов / гл. ред. Ахманова О. С. -Москва : “Советская Энциклопедия", 1966. - 608 с.

17. Словарь синонимов русского языка: В 2-х т. / под ред. А. П. Евгеньевой. - Москва : Наука, 1970 - 1971. - 1536 с.

18. Степанов Ю. С. Основы общего языкознания : учеб. пособ. для студ. филол. специальностей пед. ин-тов. / Ю. С. Степанов. - Москва : Просвещение, 1975. - 271 с.

19. Стернин И. А. Методика исследования структуры концепта / И. А. Стернин // Методологические проблемы когнитивной лингвистики. Воронеж : Изд-во Воронеж. ун-та, 2001. - C. $58-65$.

20. Уфимцева А. А. Семантический аспект языковых знаков / А. А. Уфимцева // Принципы и методы семантических исследований. - Москва, 1976. - С. 31-45.

21. Черняк В. Д. Проблема синонимии и лексико-грамматическая классификация слов / В. Д. Черняк. - Ленинград, 1989. - 118 с.

22. Cambridge Dictionary [Електронний ресурс] - Режим доступу до ресурсу: https://dictionary.cambridge.org/dictionary/english/family

23. Harris R. Synonymy and Linguistic Analysis / R. Harris. - Oxford, 1973. - 166 p.

24. Jackson H. Words and Their Meaning / H. Jackson - London, 1988. - 280 p.

\section{REFERENCES}

1. Apresjan Ju. D. Izbrannye trudy. T. 1. Leksicheskaja semantika (sinonimicheskie sredstva jazyka) [Lexical semantics] / Ju. D. Apresjan. - Moskva : Shk. “Jazyki rus. kul’tury”, 1995. $-472 \mathrm{~s}$.

2. Apresjan Ju. D. Issledovanija po semantike i leksikografii: T. 1: Paradigmatika [Research on semantics and lexicography. Paradigmatics] / Ju. D. Apresjan. - Moskva, 2009. - 568 s.

3. Balli Sh. Francuzskaja stilistika . 2-e izd., stereotipnoe [French stylistics] / Sh. Balli. Moskva : Jeditorial URSS, 2001. - 392 s.

4. Belov V. A. Tipy sinonimicheskih rjadov [Types of synonymic rows] / V. A. Belov // Voprosy psiholingvistiki. - Tom 22.- Moskva : "Moskovskaja mezhdunarodnaja akademija", 2014. - S. 125-137.

5. Budagov R. A. Ocherki po jazykoznaniju [Essays on general linguistics] / R. A. Budagov. - Moskva, 1953. - 300 s.

6. Chernjak V. D. Problema sinonimii i leksiko-grammaticheskaja klassifikacija slov [problems of synonymy and lexico-grammatical classification of words] / V. D. Chernjak. - Leningrad, 1989. - $118 \mathrm{~s}$.

7. Cambridge Dictionary [Electronic source] - Access via: https://dictionary.cambridge.org/ dictionary/english/family

8. Harris R. Synonymy and Linguistic Analysis / R/ Harris. - Oxford, 1973. - 166 p.

9. Jackson H. Words and Their Meaning / H. Jackson - London, 1988. - 280 p. 
10. Kobozeva I. M. Leksicheskaja semantika : uchebnik [Lexical semantics: A textbook] / I. M. Kobozeva. - Moskva : Jeditorial URSS, 2000. - $352 \mathrm{~s}$.

11. Lingvisticheskij jenciklopedicheskij slovar' [Linguistic envyclopedic dictionary] / gl. red. V. N. Jarceva. Moskva : Sovetskaja jenciklopedija, 1990. - $685 \mathrm{~s}$.

12. Matiiash-Hnediuk I. M. Analiz poniatiinoho skladnyka struktury kontseptu FAMILY (diakhronnyi aspekt) [Analysis of the concept FAMILY notional components] / I. M. Matiiash-Hnediuk // Zakarpatski filolohichni studii. - Vyp. 5. - Tom 1. - Uzhhorod, 2018. S. $73-77$.

13. Pashkovska N. F. Synonimichnyi riad yak movna mikrosystema [The synonymic row as a linguistic microsystem] / N. F. Pashkovska // Aktualni problemy ukrainskoi linhvistyky: teoriia i praktyka. - Vyp. 15. - 2008. - S. $158-165$.

14. Palevskaja M. F. Sinonimy v russkom jazyke [Synonyms in Russian] / M. F. Palevskaja. Moskva, 1964. - $120 \mathrm{~s}$.

15. Pimenova M. V. Konceptual'nye issledovanija. Vvedenie : ucheb. Posobie [Conceptual research: An introduction] / M. V. Pimenova, O. N. Kondratieva. - Moskva : FLINTA ; Nauka, 2011. - $176 \mathrm{~s}$.

16. Popova Z. D. Ocherki po kognitivnoj lingvistike [Essays on cognitive linguistics] / Z. D. Popova, I. A. Sternin. - Voronezh : Istoki, 2001. - $191 \mathrm{~s}$.

17. Selivanova O. O. Lingvistichna enciklopedija [Linguisic encyclopedia] / O. O. Selivanova. - Poltava : Dovkillja-K, 2010. - 844 s.

18. Slovar' lingvisticheskih terminov [A dictionary of linguistic terms] / gl. red. Ahmanova O. S. - Moskva : "Sovetskaja Jenciiklopedija", 1966. - 608 s.

19. Slovar' sinonimov russkogo jazyka: V 2-h t. [A dictionary of Russian synonyms] / pod red. A. P. Evgen'evoj. - Moskva : Nauka, 1970 - 1971. - $1536 \mathrm{~s}$.

20. Stepanov Ju. S. Osnovy obshhego jazykoznanija : ucheb. posob. dlja stud. filol. Special'nostej ped. in-tov [Fundamentals of general linguistics: A textbook] / Ju. S. Stepanov. - Moskva : Prosveshhenie, 1975. - 271 s.

21. Sternin I. A. Metodika issledovanija struktury koncepta [Methods of the concept structure research] / I. A. Sternin // Metodologicheskie problemy kognitivnoj lingvistiki. Voronezh : Izd-vo Voronezh. un-ta, 2001. - S. $58-65$.

22. Ufimceva A. A. Semanticheskij aspekt jazykovyh znakov [The semantic aspect of language signs] / A. A. Ufimceva // Principy i metody semanticheskih issledovanij. - Moskva, 1976. - S. 31-45.

23. Vasylenko V. A. Synonimiia i antonimiia u poeziiakh Ihoria Muratova [Synonymy and antonymy in the poetry of Ihoriy Muratov] : avtoref. dys. ... kand. filol. nauk : spets. 10.02.01 "Ukrainska mova" / V. A. Vasylenko. - Kharkiv, 1999. - 22 s.

24. Zvegincev V. A. Zamechanija o leksicheskoj sinonimii [Notes on lexical synonymy] / V. A. Zvegincev // Voprosy teorii i istorii jazyka: Sbornik v chest' prof. B. A. Larina. - Leningrad, 1963. - S. $137-138$. 


\title{
SEMANTIC ANALYSIS OF THE SYNONYMS OF THE CONCEPT FAMILY
}

\section{Iryna Matiiash-Hnediuk}

\author{
Vasyl Stefanyk Precarpathian National University, \\ 57, Shevchenko Str., Ivano-Frankivsk, Ukraine, 76000 \\ irynamatiiashhned@gmail.com
}

The article attempts to analyze the synonyms of the concept FAMILY based on the lexicographic analysis of the synonyms of the nominative lexeme of the concept by grouping them into synonymic rows and considering the shades of meanings of the synonyms. Modern linguistic studies are mostly characterized by a cognitive approach. Most attention is paid to the research of such cognitive formations as concepts. One of the stages of concept structure designing is the analysis of synonyms of the lexeme which names the concept. It is performed to conduct an exhaustive analysis of a notion constituent of the concept investigated. Synonyms are the words which have the same lexical meaning, but different shades of it. Words that are used for expression of the same concept or phenomenon of objective reality form a synonymic row. The synonymic row is examined as a subsystem in the general system of language. It is characterized by openness. Language regularities are reflected in the changes of synonymic rows as well as in their origin, increase or reduction of their constituents, and elimination. Defining of synonymic rows is relatively arbitrary, as it is often difficult to say if a word realizes a new completely different meaning, which makes it possible to use it as a basis for a new semantic row, or if only an additional stylistic colouring of a dominant of the same row is represented. Synonymic rows are open and changeable. Within a synonymic row, words are grouped according to their semantic similarity, differing only by their shades of meaning, usage, and emotional colouring. A synonymic row is organized around one lexeme, the meaning of which is general for all synonyms of this row. Its meaning is the same as the semantic basis of the row. It names a concept, but does not specify or characterize it. Such lexeme is the dominant of a synonymic row.

Based on seven dictionaries of synonyms and thesauruses, the synonymous lexemes of the name of the analyzed concept FAMILY have been defined. Seven synonymic rows have been singled out: 1) "a group of people according to the criterion of homogeny", 2) "a group of people related by blood or marriage", 3) "a group of homogeneous objects and phenomena", 4) "children of a person or a couple", 5) "a group of people united by the similarity of interests, persuasions, oractivity", 6) "social group", 7) "noble origin". Additional notional features of the analysed concept were revealed through the synonymic analysis, namely, group of things, genealogy, association, social group, aristocracy.

Key words: synonymy, synonymic row, dominant, lexeme, noun, concept. 